

\section{VOL. XVII.-1902.}

THE

\section{JOURNAL OF LARYNGOLOGY,}

\section{RHINOLOGY, AND OTOLOGY;}

AN ANALYTICAL RECORD OF CURRENT LITERATURE

RELATING TO

\section{THE THROAT, NOSE, AND EAR.}

PUBLISHED MONTHLY.

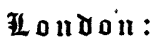

REBMAN, LIMITED, 129, Shaftesbury Avenue, Cambridge Circus, W.C: 


\section{THE JOURNAL OF LARYNGOLOGY RHINOLOGY, AND OTOLOGY.}

Founded in 1887 by MORELL MACKENZIE and NORRIS WOLFENDEN.

EDITORs :

JOHN MACINTYRE, M.B., M.Ch., F.R.S.E.

DUNDAS GRANT, M.A., M.D., F.R.C.S. Eng.

ARTHUR SANDFORD, M.D., M.Ch.R.U.I.

R. LAKE, F.R.C.S.

W. MILLIGAN, M.D., Sub-Editor.

W. JOBSON HORNE, M.A., M.D.; B.C. Cantab., M.R.C.P. Lond., Managing Sub-Editor.

WTTH THE CO.OPERATION OF

Drs. Baron (Bristol), Prick-Brown (Toronto), Cartaz (Paris),

Bryson Delavan (Nex York), Dond (Chicago), Donklan (London),

Grazzi (Florence), Guye (Amsterdam), Hrcguet (Brussels),

Mrodlemass Hunt (Liverpool), Hutohison (Brighton), Joal (Paris),

Kelly (Glasgow), Lacoarket (Toulouse), Lichtwitz (Bordeaux),

Lieven (Aix-la-Chupelle), John N. Mackenzie (Baltimore), Prot. Massei (Naples),

Mryjes (Amsterdam), Mrles (New York), Holger Mrgind (Copenhagen),

Porter (St. Louis), Guthd (Dundee), Sachs (Hamlnurg),

StGeorge Reid (London). Sajous (Philadelphia), Sextziak (Warsaw),

Sota (Seville), StClair Thouson (London), WaggetT (London),

Woons (Dublin), and Zrem (Dantzic). 


\section{LIST OF PLATES.}

Portrait of the late Dr. Achille Gouguenheim To face p. 1

Plates I., II., III., IV., V.-To illustrate Dr. Christian R. Holmes' Paper on Enormous Naso-Pharyngeal Soft Fibroma - - - - - To face pp. 400, 402, 410

Plates I., II., III.-To illustrate Dr. John Macintyre's Paper on the Diagnosis and Treatment of Foreign Bodies in the Upper Air Passages and Gullet

To face $p p .470,472,474$

Plates I.-VIII.-To illustrate Dr. Gustay Killian's Paper on Short Hints for Examining the Esophagus, Trachea, and Bronchi by Direct Methods - To face pp. 505, 506, 508

Portrait of the late Mr. Lennox Browne - To face p. 629 


\section{CONTENTS.}

Special Article-

PAGE

Short Hints for Examining the Esophagus, Trachea, ami Bronchi by Direct

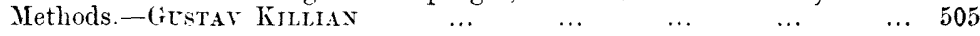

British Medical Association-

Seventieth Amnual Meeting. Sections of Laryngology and Otology : A Case of Papillomatous Excrescences, or Ozienic Incrustations, or Chalky Deposits, or other Lesion low down in the Trachea.-EDwap LAw ${ }^{*}$.. $\quad .$.

The Present State of the "Ozena" Ouestion.-L. GrërwaLD $\quad \ldots \quad$ _.. 514

Remarks on Cholesteatoma of the Middle Ear.-Duxdas Graxt $\quad \ldots \quad$.. 518

Societies' Proceedings-

Eighth Axycil Mentixg of the Avenicax Liprygolugical, RhixolOGICAL, AND OTOlogical Sorietr. Communications by Edward B. Dench, George L. Richards, (i. Hudson Makuen, Joselh T. Gihb, John O. IIcReynolds, Wm. L. Ballenger, W. Freudenthal, Frank E. Miller, James F. McCaw, C. Dunlar Roy, D. J. Gibh, Wishart, W. H. Haskin, Thomas H. Farrell, Wendell C. Phillips, Ewing W. Day, T. Passmore Berens, Henry J. Hartz, Thomas J. Harris, Walter A. Wells, Thomas H. Halstegd

$\begin{array}{llllllll}\text { LAYYYGOLOGICAI SOCIETY OF LONDOX ... } & \ldots & \ldots & \ldots & \ldots & 544\end{array}$

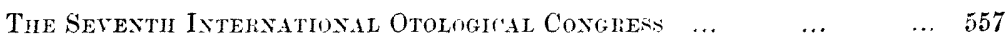

\section{Abstracts-}

Nose Axd N.so-rharrxx. - Hypertrophic Rhinitis and its Sequele Cnilateral Nasal Hydrorrhcea cured by Hot Air $\quad \ldots \quad \ldots \quad \ldots \quad \ldots \quad 557$

LAnxxy. - Tuberculosis of the Larynx in a Man of Sixty-two $\quad \ldots \quad \ldots \quad \ldots \quad 558$

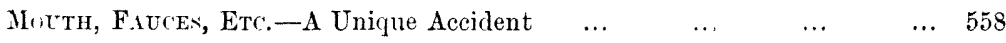

ExR. - The Venous System of the Temporal Bone and its Relation to the $\begin{array}{lllllll}\text { Complications of Mastoid Disease } & \ldots & \ldots & \ldots & \ldots & \ldots & 558\end{array}$

\section{Review-}

Beitrige zu der Fun.ti-numter-iuhum-1n an Taubstummen in Dinemark ("Con-

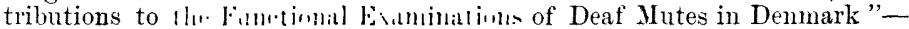

\section{GUIDE TO ADVERTISEMENTS.}

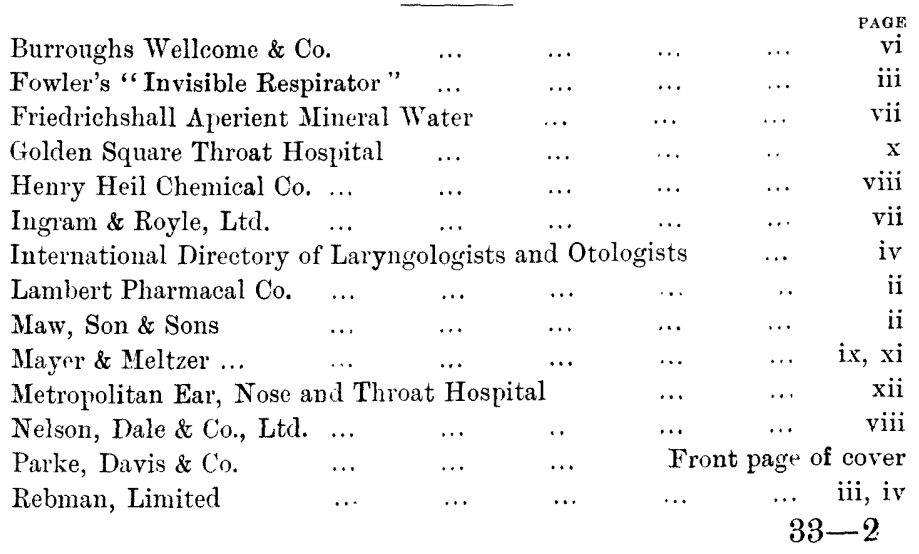




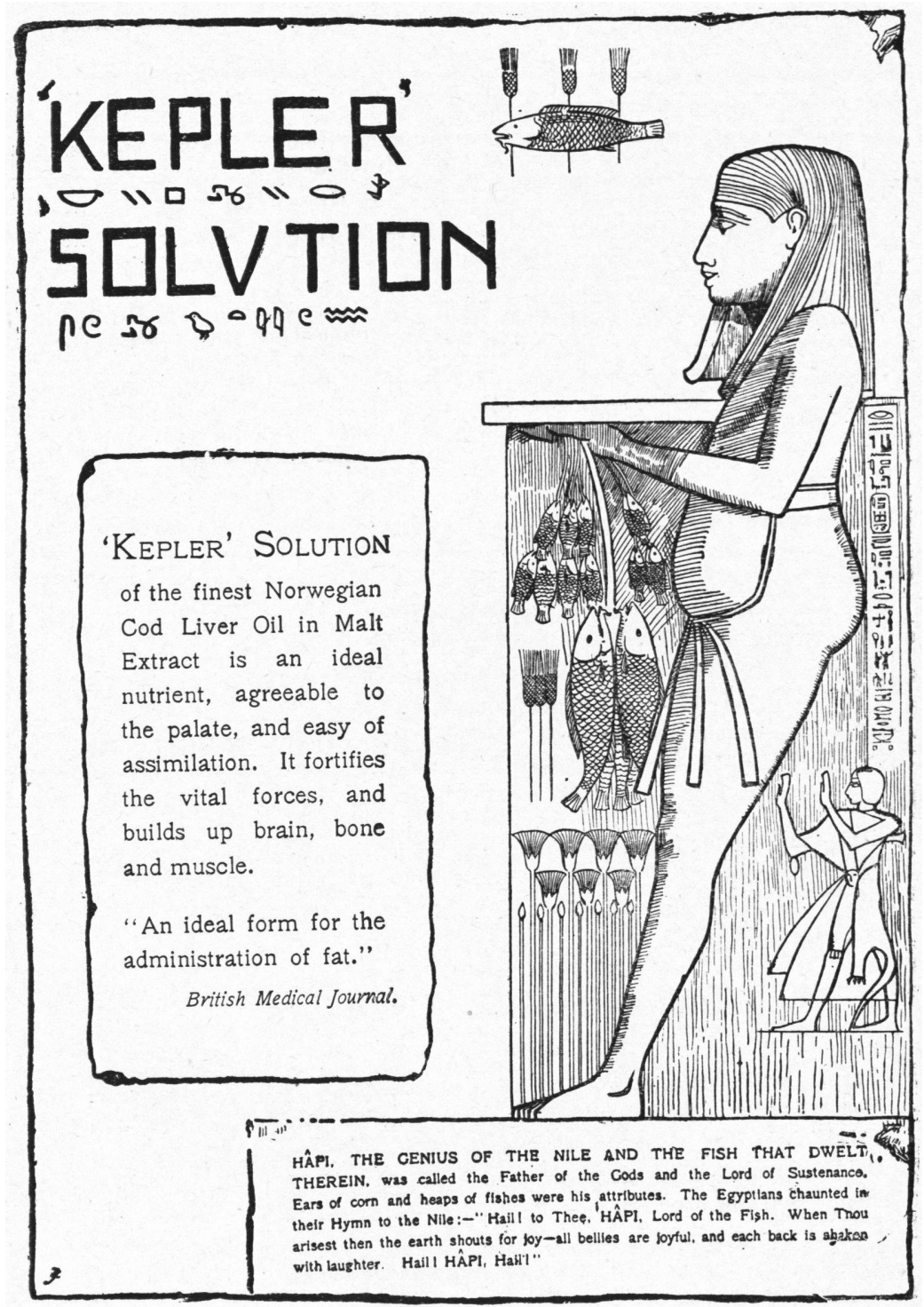

Burroughs Wellcome \& Co., london and sydney. [COPYRIGH] 